\title{
THE CHURCH OF ENGLAND: SOME HISTORICAL REFLECTIONS ON A CONSTITUTIONAL CONUNDRUM
}

\author{
Charlotte Smith, Law School, University of Reading
}

\section{Introduction}

In recent years the conundrum of the constitutional and legal position and treatment of the Church of England has frequently been brought to the fore. Reform of the House of Lords and of the blasphemy laws has raised it in the context of initiatives for constitutional reform. Similarly, the implementation of the Human Rights Act 1998, and in particular the developing jurisprudence on the definition of public authorities under $s 6$, has raised questions for the judicial treatment of the Church of England and its institutions. That the Church of England represents a conundrum for modern policy-makers and judges has, it will be argued, been decisively demonstrated in the case of Aston Cantlow v Wallbank, ${ }^{1}$ which concerned the status of Anglican parochial church councils under s6 of the Human Rights Act.

This article seeks to cast light on the conundrum, firstly by examining what Establishment means in practical terms, and then by exploring it from the perspective of Church history in the last two hundred years. It will examine the constitutional, political and social changes which challenged the existence of an unproblematic connection between Church, State and nation, ${ }^{2}$ and Church reactions to those changes. In doing so it will identify the ambiguities created by Establishment, and will illustrate how the changes of the later nineteenth century, continued and developed down to the present time, have created problems for modern attempts to address the legal and constitutional status of the Church of England.

Having sought some lessons from history, this article will conclude by demonstrating the applicability of the historical debate relating to Establishment to modern difficulties relating to the treatment of the Church of England. In doing so it will also comment, albeit briefly, on some of the other reasons why modern judges and policy-makers find it so difficult to give adequate attention and effect to the impact of the Church's historical and continuing Establishment.

1 [2003] UKHL 37 and [2001] EWCA Civ 713.

2 On this point see generally R. Brent, Liberal Anglican Politics: Whiggery, Religion, and Reform, 1830-1841 (Oxford: Clarendon Press, 1987); A. Burns, 'The Costs and Benefits of Establishment: Clergy-Discipline Legislation in Parliament, c. 1830-c. 1870,' Parliamentary History (2000); and F. Knight, The Nineteenth Century Church and Society (Cambridge University Press, 1995). 


\section{Defining Establishment}

Like almost every aspect of the organic and evolving British constitution, Establishment is extremely difficult to define and quantify with any reasonable degree of precision. As Paul Avis remarks:

"The establishment is a given history, a complex tissue of customary and statutory arrangements deeply embedded in the way society conducts its most serious affairs. Establishment has been profoundly modified and reformed over the past 400 years and will go on evolving. No one particular concrete expression of it is sacrosanct."

In its original formulation, in the Reformation Statutes, it appears that it merely signified that the Church had been settled or stabilised following a period of political instability and change. Thus the Latin rendering of the words 'by law established' in the Canons was legibus stabilitam. ${ }^{4}$ Over time, however, Establishment has come to mean far more than this. At its most basic level it embodies a relationship between Church and State which is distinct from that enjoyed by other religious bodies. In the words of Lord Selborne:

"The "Establishment" of the Church of England consists in certain relations, different from those of other religious bodies, in which the Church of England now stands towards the State, or the Public Law and Government of the country." 5

The central features of State recognition and support of the Church, and some degree of State authority and influence in its affairs, typify this special relationship. ${ }^{6}$ It is, in its essence, an assertion that religion is, in part at least, a public matter with which the State may (should) concern itself. It asserts that the State has a duty to provide for the moral and spiritual welfare of its citizens and that the Church, supported and recognised by the State, is the means by which the State fulfils that duty. ${ }^{7}$ As such Establishment exists in two aspects. In part it refers to a relationship between the Church and the institutions of the State, that is, to Parliament and the Crown. Establishment also, however, refers to the relationship between the Church and the citizens of the State, that is, to the nation.

\section{Seeking Lessons in History: Church and State in The Nineteenth Century and The Creation of The Conundrum}

What follows is an attempt to trace relations between Church, State, and nation in the nineteenth century, and to identify the historical and theological

3 P. Avis, Church, State and Establishment (London: S.P.C.K., 2001) p.34.

4 ibid., pp.18-19.

5 R. Palmer, The Endowment and Establishment of the Church of England. An Address Delivered at Blackmoor on Monday, January 11, 1866 (London: Cassell and Co., 1886) p.3.

6 Although this State authority may be weakened beyond any significant meaning as in the present Establishment of the Church of Scotland.

7 For a good overview of Anglican Church-State theory see generally P. Avis, Church, State and Establishment. 
forces which, it will be argued, have contributed to current difficulties regarding the legal and constitutional treatment of the Church of England.

\section{Establishment as a Relationship between the Church and the Organs of the State - The Legal and Constitutional Aspect}

Almost from its birth the Church has enjoyed an intimate relationship with the Crown, reflected in the role of its bishops as royal advisers and councillors, and in their right to sit in the House of Lords as advisers, representatives of the people and the owners of significant tracts of land. At the Reformation this relationship came, by virtue of the need to exclude the foreign jurisdiction of the Pope, to focus, and to pivot upon, the Royal Supremacy. This was embodied in section 8 of the Act of Supremacy 1558, ${ }^{8}$ which affirmed that:

"And ... that suche jurisidctions privileges superiorities and preheminences spirituall and ecclesisticall, as by any spirituall or ecclesiasticall power or aucthorite hathe heretofore bene or may lawfully be exercised or used for the visitacion of the ecclesiastical state and persons, and for reformacion order and correcion of the same and of all maner of errours scismes abuses offences contemptes and enormities, shall for ever by aucthorite of this present Parliament be united and annexed to the imperiall crowne of this realme; ..."

The first practical expression of this was found in the law regulating the appointment of bishops. ${ }^{9}$ Having excluded the jurisdiction of the Pope Henry VIII first asserted the right to make all Episcopal appointments in the Appointment of Bishops Act 1533. ${ }^{10}$ Under the process established by this Act the Dean and Chapter of the relevant see were granted a licence (the congé d'élire) to appoint a bishop under the Great Seal. However a letter missive, stating the name of the person to be appointed, accompanied the licence.

The second practical manifestation of this relationship was found in the role of the Crown in the promulgation of Anglican canon law. By the Act of Supremacy 1533, and the Act of Submission of the Clergy 1534, ${ }^{11}$ the clergy recognised the Crown as their law-maker, and forfeited any right to legislate for Church matters independently of the Crown. Under s1 of the Submission of the Clergy Act the Crown's licence and assent were required before canons made in the Convocations of the Church could be promulgated. By section 3 of that Act it was declared that the Church could not pass canon law which was contrary to the royal prerogative, the common law, statute law or other customs of the land.

A third practical consequence of Establishment was the role of the Queen in Parliament in the government and general law-making of the Church. The general effect of the Act of the Submission of the Clergy 1534 was to vest in Parliament a wide authority in ecclesiastical matters. By that Act the

$8 \quad 1$ Eliz. c. 1

9 And certain other senior officers of the Church.

1026 Henry 8 c. 1 .

1126 Henry 8 c. 1 . 
Convocations of the Church were unable to meet except at the behest of the Monarch. In fact these bodies were moribund for much of the period leading up to the $1850 \mathrm{~s}$, with the result that, in practice, the Church had for a long period no national body except Parliament in which to deal with its administration and government. Similarly, just as the Church had no power to pass canon law except by the licence and assent of the Crown, it had no power to pass ecclesiastical legislation binding upon both the clergy and the laity. In practice, if legislation was required, it had to rely on the intervention of Parliament.

A further consequence of Establishment was found in the character and status of Anglican ecclesiastical law. That body of law was heterogeneous in character. It was comprised of Canons passed before the Reformation, ${ }^{12}$ Canons promulgated by royal licence after the Reformation, ${ }^{13}$ statutes, ${ }^{14}$ and things done pursuant to statutory or prerogative powers. ${ }^{15}$ However, whatever form that ecclesiastical law took it formed part of the ordinary law of the land and was ultimately enforceable as such. In this respect it was fundamentally different to the law of other religious organisations, a situation identified by many as being the essence of Establishment. ${ }^{16}$

The final result of Establishment was the legal position granted to the ecclesiastical courts of the Church of England. The first aspect of this was the coercive jurisdiction which the State conferred upon those courts. These were recognised as public courts whose judgments were enforced in the last resort by the coercive powers of the State. Further, the final appeal in ecclesiastical causes was to the Crown. ${ }^{17}$ This appellate jurisdiction was exercised by the Court of Delegates until 1832, when it was transferred to the Judicial Committee of the Privy Council by the Privy Council Appeals Act of that year. ${ }^{18}$

\section{Anglican Theory and Ideology}

As demonstrated, Establishment resulted in a close relationship between Church and State. This relationship has been the subject of much theorising in the centuries following the Reformation, reflecting the fact that Establishment consists not only of a legal framework, but also of a web of theory and sentiment which has grown up around the law. ${ }^{19}$

Historically one of the most prominent features of Establishment theory was that Establishment was founded upon the idea of a union or unity of Church and State. Just as the Royal Supremacy was seen at the foundation of the

12 Henry VIII expressed his intention at the Supplication of the Ordinaries, 1532, to subject this body of law to a commission of review but this work was never done.

13 Such as the canons of 1603.

14 Such as the various Acts of Uniformity.

15 Such as the Book of Common Prayer of 1662 and the Articles of Religion.

16 For statements on this point see R. Palmer, The Endowment and Establishment of the Church of England, p.43 and the Acts disestablishing the Churches of Wales and Ireland.

17 See the Act in Restraint of Appeals 1533, 24 Henry 8 c. 12 .

182 \& 3 Will. 4 c. 92

19 See P. M. H. Bell, Disestablishment in Ireland and Wales (London: S.P.C.K., 1969) introduction and chapter one. 
legal expressions of Establishment so, too, it was found at the heart of the union or unity of Church and State. Church and State were united under the Queen as temporal governor of both.

The essential unity of Church and State was expressed by many thinkers in the idea that Church and State were the same body - the nation - seen from different perspectives. This theory was best known in connection with the writing of divines such as Richard Hooker ${ }^{20}$ and Edmund Burke. ${ }^{21}$ It was also famously expressed in the nineteenth century by, among others, Thomas Arnold and Samuel Taylor Coleridge. Thomas Arnold, for example, idealising the union of Church and State, and arguing against the fragmentation of life into secular and spiritual elements, wrote:

"The natural and true state of things then is, that this power and this wisdom [of Church and State] should be united; that human life should not be pulled to pieces between two claimants, each pretending to exercise control over it, not in some particular portion, but universally; that wisdom should be armed with power, power guided by wisdom; that the Christian Church should have no external force to thwart its beneficent purposes; that government should not be poisoned by its internal ignorance or wickedness, and thus advance the cause of God's enemy, rather than perform the part of God's vicegerent." 22

Coleridge maintained a careful distinction between the nation - of which the Church was a part - and the State - of which the Church was not a part, but to which it was joined. He also distinguished between the national Church which was joined in a relationship with the State - and the universal Church - which owned no temporal allegiances and looked to Christ alone as its authority. Despite making these careful distinctions he too was clearly concerned to demonstrate the essentially close relationship between Church and State. He instructed his readers in this using the following parable:

"As the olive tree is said in its growth to fertilise the surrounding soil, to invigorate the roots of the vines in its immediate neighbourhood, and to improve the strength and flavour of the wines; such is the relation of the Christian and the national Church. But as the olive is not the same plant with the vine, or with the elm or poplar, (that is, the State) with which the vine is wedded; and as the vine with its prop may exist, though in less perfection, without the olive, or previous to its implantation; even so is Christianity. .."23

In both quotations a further aspect of Establishment was drawn to the attention of the reader. This union or unity of Church and State, or perhaps of Church and nation, existed for a reason. At its heart was an assumption that the State, by virtue of Establishment, was in some way underpinned by

20 (1554-1600). His most famous work is Of the Laws of Ecclesiastical Polity.

21 (1729-97).

22 T. Arnold, Fragment on the Church ( $2^{\text {nd }}$ ed.) (London: B. Fellowes, 1845) p.11.

23 S. T. Coleridge, On the Constitution of Church and State According to the Idea of Each ( $3^{\text {rd }}$ ed.) (London: William Pickering, 1869) p.6o. 
the Christian faith of the Church to which it was joined, and that the mission of the Church was benefited thereby. ${ }^{24}$ Thus, for both Coleridge and Arnold, the essential virtue of the union of Church and State was that it furthered the mission of those bodies to fight evil and to improve the moral state of man. In this idea was found another bulwark of the constitutional relationship of Church and State, that is, the idea that not only did the Church have a spiritual identity and authority but so, too, did the State.

One of the most obvious foundations of the spiritual identity and authority of the State was found in the Royal Supremacy. This articulated the belief that the Monarch, under whom Church and State were united, was a species of spiritual person, though not a priest, whose authority was derived from God. ${ }^{25}$ Article XXXVII of the Articles of Religion expressed this in the following words:

"Where we attribute to the King's Majesty the chief government ... . we give not to our princes the ministering either of God's Word, or of the Sacraments. . . but that only prerogative, which we see to have been given always to all godly Princes in holy Scriptures by God himself; that is, that they should rule all estates and degrees admitted to their Charge by God, whether they be Ecclesiastical or Temporal, and restrain with the civil sword the stubborn and evildoers."

Equally important to the spiritual identity of the Church, especially as Parliamentary Sovereignty assumed its place as the keystone of the British Constitution, was the identification of Parliament as a spiritual body. Hence its traditional identification as the 'King/Queen in Parliament under God.' Like the Monarch it acted under the authority of God. Of equal importance to the Church, perhaps, was the identification of Parliament as being, in matters of ecclesiastical legislation, a lay synod. This identity was maintained until the nineteenth century by legislation limiting membership of Parliament to men who conformed with the Church. Acts such as the Tests Acts of $1673^{26}$ and $1678^{27}$ and the Corporation Act of $1661^{28}$ ensured that those participating in the political life of the nation were, at least as judged by their actions, in communion with the Church.

\section{Anglican Theory and Ideology Challenged: Lessons from the Nineteenth Century}

From the middle of the nineteenth century the evolution and reform of the British constitution required Establishment's supporters to respond to novel challenges as the character of that constitution changed. At the most basic level these changes refuted categorically the assumption that the close relationship of Church and State was to be supported because it demonstrated that the State was founded upon Anglican religion. When the State repealed

${ }^{24}$ See P. Avis, Church, State and Establishment.

25 For a more detailed discussion of this see I. M. Mackenzie, God's Order and Natural Law: The Work of the Laudian Divines (Aldershot: Ashgate, 2002) chapter five.

2625 Car. 2 c. 2.

2730 Car. 2 c. 1 .

2814 Car. 2 c. 1 . 
the Tests and Corporation Acts in 1828, passed the Roman Catholic Relief Act $1829,{ }^{29}$ and later the Jews Relief Act $1858,{ }^{30}$ it demonstrated that there had been a shift in favour of a State founded upon democratic and pluralist principles.

Despite the changes to the constitution embodied in the Reform Acts, and in the progressive removal of the civil disabilities of Protestant Dissenters, Roman Catholics, Jews and atheists, there was no generalised challenge to the role that Christianity played in the Constitution. Many thinkers continued to defend that role, and the continued Establishment of the Church of England, on the basis that the services of religion morally improved men, and that there was a link ${ }^{31}$ between religion, morality and the foundation of a democratic society ruled by law rather than force. ${ }^{32}$ Thus Lord Selborne, defending Establishment, announced his conviction that:

"The mainstay of all law . . . is . . . the moral sense of mankind; religion, wherever it is truly professed, is . . . powerful in the direction and reinforcement of that moral sense." 33

Many supporters of Establishment also continued to defend Establishment on the basis that the Established Church was best able to provide for the spiritual needs and moral education of the nation, and that this was both necessary to - and a duty of - the democratic State. ${ }^{34}$ Thus Gladstone argued that the alliance of Church and State was 'calculated to extend and establish the vital influences of Christianity, and therewith to increase and purify the mass of human happiness.' 35 Similarly, Spencer Holland asked:

"Can the State when aware that masses of people will never seek any form of religion or moral training of their own accord, and of the inability of private resources to cope with the wants of great populations hurried and worried with much service,- can it wash its hands of all responsibility, and blandly reply, “Am I my brother's keeper?"'36

Given this viewpoint many writers, even late into the nineteenth century, continued to identify the State as being in some sense a spiritual or divinely ordained body. Lord Selborne, for example, calmly asserted that:

"Both powers, the Ecclesiastical and the Civil, are... in their origin divine; each has its proper province, the persons over which each exercises its authority are to a great extent the

2910 Geo. 4 c.7.

$3021 \& 22$ Vict. C. 49

31 Now rejected. See HL Paper 95-I, appendix three on religious offences.

32 See, e.g. S. T. Coleridge, On the Constitution of Church and State, p.58 and S. Holland, The National Church of a Democratic State (London: Rivingtons, 1886) p.5.

33 R. Palmer, A Defence of the Church of England (5 ${ }^{\text {th }}$ ed.) (London:Macmillan \& Co, 194), p.73.

34 See e.g. Coleridge, On the Constitution of Church and State, p.78 and S. Holland, The National Church of a Democratic State, p.8.

35 W. E. Gladstone, The State in its Relations to the Church (2 Volumes) (4 ${ }^{\text {th }}$ ed.) (London: John Murray, 1841) p.3.

36 S. Holland, The National Church of a Democratic State, p.10. 
same; and there is, by the unchangeable laws of nature and Providence, a middle or common ground between them." ${ }^{37}$

However two of the ideas underpinning the spiritual identity of the State were fundamentally undermined by the constitutional changes effected between 1689 and the nineteenth century. The first idea affected in this way was that of the spiritual identity of the Monarch. So threadbare was this seen to be in reality that, speaking to a gathering of Churchmen in 1882, one conservative Churchman was moved to dismiss it out of hand, ${ }^{38}$ saying:

"The theory of an anointed king as being a sort of mixta persona - part secular and part spiritual - though of considerable age, I should hardly consider as worthy of serious discussion." $" 39$

There were four key features of Divine Right which helped to underpin that spiritual identity: the idea that the Monarchy was a divinely ordained institution, the indefeasibility of the hereditary right of the Monarch, the idea that the Monarch was accountable to God alone, and the principle that nonresistance and passive obedience were ordained by God. ${ }^{40}$ Two of these features were swept aside by the Glorious Revolution. The interruption of the Succession in 1689 destroyed the practical reality of any argument for the indefeasibility of the hereditary right of the Monarch. The victory of the notion of Parliamentary Sovereignty and the constitutional or limited Monarchy, as embodied in the Bill of Rights 1689, was fatal to the principle of a Monarch answerable to God alone.

The identification of Parliament as the lay synod of the Church, another manifestation of the spiritual identity of the State, was also undermined. When, under the legal changes of the nineteenth century, Parliament admitted Protestant Nonconformists, Roman Catholics, Jews and even nonbelievers to its seats, its identity as a lay synod for the Church, or even a Christian legislature, was increasingly lost from sight.

When the State embraced pluralist principles, and when its spiritual identity was obscured, it was perhaps unavoidable that the traditional concept of the unity or union of Church and State should be called into question. Thomas Arnold, that most ardent supporter of the unity of Church and State as different aspects of the nation, gave a warning to this effect when he asserted that the nineteenth century Church was not as one with the State. While arguing that this situation had no logical or rational foundation in theory he nevertheless maintained that Church and State were in fact separate and out of step. ${ }^{41}$

This feeling that Church and State, though still unified or united by law were in fact and theory divided and increasingly distinct, was fostered by the

37 R. Palmer, A Defence of the Church of England against Disestablishment, p.73. See also W. E. Gladstone, The State in its Relations to the Church, p.50.

38 Although see I. Bradley, God Save the Queen: The Spiritual Dimension of the Monarchy (London: D.L.T., 2002) for a discussion of the continuing spiritual role or identity of the monarch.

39 Earl Nelson, 'Church and Crown,' Report of Church Congress (1882) p.201.

40 N. Figgis, The Theory of the Divine Right of Kings (Cambridge, 1896) pp.5-6.

41 T. Arnold, Fragments on Church and State (London: B. Fellowes, 1845), pp.57-9. 
theological concerns of, among others, one prominent group of Anglican thinkers. The Oxford Movement, reacting to the constitutional change and uncertainty of its times, sought for the Church an identity and authority entirely separate from its relationship with the State. Its members found this in an emphasis upon the authority and identity of the Church of England as part of the Church of Christ. In doing so, however, they threw into stark relief a distinction between the earthly and man-made authority of the State, and the God-derived spiritual authority of the Church. In a characteristic statement, for example, one of their leaders cried:

"CHRIST has not left this Church without claim of its own upon the attention of men . . . I fear we have neglected the real ground upon which our authority is built, - our APOSTOLICAL DESCENT.

We have been born, not of blood, nor of the will of the flesh, nor of the will of man, but of God. The Lord JESUS CHRIST gave His Spirit to His Apostles; they in turn laid their hands upon those who would succeed them; and these again on others; and so the sacred gift has been handed down to our present Bishops, who have appointed us as their assistants, and in some sense representatives." ${ }^{2}$

\section{Establishment as a Relationship between the Church and the Nation - The Aspiration and Manifestation of a National Church}

The Church of England has historically aspired to the status and role of a national church. This was most strongly evident in its approach to three main areas of its life: the definition of its aim and mission; the definition of its community or membership; and its pastoral and administrative organisation.

Turning first to the mission of the Church of England as a national Church, the essential feature was that it defined that mission in relation to the nation as a whole. It aspired to serve all citizens living in the State. In the words of a nineteenth century theologian:

"That which is essential to a national Church is, that it should undertake to assist the spiritual progress of the nation and of the individuals of which it is composed, in their various states and stages. .." 43

This identification of the mission of the Church as being a mission to the nation as a whole reflected the history of the Church as a manifestation of public provision for the religious needs and spiritual welfare of the nation. ${ }^{44}$

42 J. H. Newman, 'Thoughts on the Ministerial Commission,' in Tracts for the Times (London: J. G. \& F. Rivington, 1839) p.2.

43 H. B. Wilson, 'Seances Historiques de Geneve,' p207 in Essays and Reviews $\left(12^{\text {th }}\right.$ ed.) (London: Longmans, 1969) $\left(1^{\text {st }}\right.$ ed., 1860). Wilson was condemned by Convocation for this essay but the point he made about the mission of the Church was uncontroversial.

44 For a full elucidation of these ideas see the memorandum of A. Pearce to the Joint Committee on Human Rights - published as an appendix to its $7^{\text {th }}$ report of the 2003-4 session (HL 39, HC 382). 
This was further reflected in the Anglican approach to the definition of its community or membership.

Historically it was seen as wholly fallacious to talk of the membership of the Church of England as a body discrete from the nation as a whole..$^{45}$ The Church began its life as a national church at a time when membership of Church and State was broadly co-extensive. Throughout much of its postReformation history civil and ecclesiastical law co-operated to maintain this idea of co-extensive membership, acting ruthlessly to solve the problems posed by incipient dissent. Hence dissenters, falling into the category of schismatics, were denounced and rendered ipso facto excommunicate by canons 9 and 12 of $1603 .{ }^{46}$ Excluded from the membership or community of the Church under canon law, dissenters were further excluded from the political life of the nation by the action of statute. Prior to the constitutional reforms of the nineteenth century Acts such as the Test Acts of 1673 and $1678,{ }^{47}$ and the Corporation Act of $1661^{48}$ ensured that dissenters were excluded from the civic life of the nation. ${ }^{49}$ Historically, then, the Church was able to adopt an involuntary model of membership. Citizens of the State did not have to take positive steps to become members of the national Church, rather, they were assumed to be members unless they took positive steps to set themselves outside of its community.

Even following the reforms of the nineteenth century, which broke the link between religious affiliation and participation in the full civic life of the nation, and even in the face of religious pluralism and diversity, the nationality-based and involuntary model of Church membership continued..$^{50}$ Generally speaking it was for any individual to determine the question of membership. If he claimed to be a member, and if he wished to avail himself of its services, then both the Church and the law vindicated his claim. In the words of Lord Selborne:

"It has sometimes been said that every Englishman is a member of the Church of England ... I imagine that few Dissenters are in the habit of so describing themselves ... It is true, now as much as ever, that the Church does not repel from the rights and privileges of Church membership any persons, baptized and not excommunicated, who honestly seek, or

45 Although for various attempts to do so for legal purposes see, e.g. General Assembly of the Free Church of Scotland v Lord Overtoun [1904] AC 612-3, per Lord Halsbury; Re Selby's Will Trusts [1966] 1 W.L.R. 43 - per Buckley J; Marshall v Graham [1907] 2 KBD 112, at 124 per Lord Alverstoke CJ; Re Perry Almshouses [1898] 1 Ch 400 - per Stirling J. It can be noted that these cases tend to determine when a claim of membership should not be rejected, rather than defining a test of membership per se.

46 G. Bray (Ed.), The Anglican Canons 1529-1947 (Boydell Press: Church of England Record Society, Vol. VI, 1998)

4725 Car 2 c. 2 and 30 Car 2 c. 1 respectively.

4814 Car 2 c. 1 .

49 Although successive Indemnity Acts were passed after 1727, mitigating the effects of these statutes.

50 Although see generally M. J. D. Roberts, The Role of the Laity in the Church of England c1850 - 1885 (DPhil, Oxford 1974) for a discussion of the modifications to, and pressures upon, this model of membership. 
willingly accept them. It is also true that the law does not, without proof of the fact, presume any man to be a Dissenter. But the question is one of fact. The law is not so unreasonable as to call the same man at the same time a Churchman and a Dissenter." 51

The identification of the Church as a national institution, comprehending and ministering to all within that nation who did not reject its services, was reflected in the traditional organisation and administration of the Church: the parochial and territorial systems. These were the means by which it supported that mission.

Under the parochial and territorial systems the infrastructure of the Church stretched across the geographical bounds of the State and was entrenched within its physical fabric. Dividing the country into progressively smaller geographical units, first into provinces, and then into dioceses, archdeaconries, rural deaneries and parishes, they provided a system of religion which served every region and every inhabitant of the land, provoking Coleridge to the following paean of praise:

"That to every parish throughout the kingdom there is transplanted a germ of civilization; that in the remotest villages there is a nucleus, round which the capabilities of the place may crystalize and brighten; a model sufficiently superior to excite, yet sufficiently near to encourage and facilitate, imitation, the unobtrusive, continuous agency of a Protestant Church Establishment, this it is which the patriot and the philanthropist, who would fain unite the love of peace with a faith in the progressive amelioration of mankind, cannot estimate at too high a price." ${ }^{52}$

The historic legal rights of the laity in respect of the Church were defined within this framework.

The first legal right of the laity was to attend the public services of the Church. As Cockburn LCJ asserted, in $R$ v The Bishop of Oxford:

"The Church is upheld and exists for the spiritual benefit of the laity. It is the right of the latter to take part, under the ministration of the clergy, in the public worship . . . according to the ritual of the Church as by law established." 53

Every English man, woman and child, not being excommunicate, had a legal right to attend the public services of the national Church performed according to law. The expression of this right reflected the lineaments of the parochial system. In Taylor $\mathrm{v}$ Timson, for example, it was made clear, both that the incumbent of every parish had a duty to provide and perform the services of the Church according to law, and that there was a general right for an individual to attend the services of his parish church. ${ }^{54}$ In other words

51 A Defence of the Church of England Against Disestablishment, pp.195-196

52 S. T. Coleridge, On the Constitution of Church and State According to the Idea of Each, p.78.

53 (1878-79) 4 Q.B.D. 260

54 (1888) 20 Q.B.D. 671. 
the rights of the laity in any particular church were determined by the geographical relationship between any particular layman and the church.

The legal right to attend the public services of the Church was not the only right of citizens in respect of the Church. Other rights included the right to have their children baptised there, the right to be buried in the churchyard and the right to be buried according to the rites of the Church of England. ${ }^{55}$

The system of religious provision and legal rights just described was, until the later nineteenth century, supported by a system of public taxation in the form of church rates and tithes. In addition to these, and still persisting today, there were the historic endowments of the Church in the form of rectoral and glebe lands. Together these sources of funding, property rights and obligations were designed to provide for the upkeep of parish churches and the maintenance of the parochial clergy. ${ }^{56}$ The rector of the parish was legally entitled to the full ecclesiastical dues of a parish under law and was consequently under a duty to keep the chancel of the church in a state of repair. ${ }^{57}$ If the rector was a lay person, meaning that the cure of souls was placed in the hands of a vicar, then the incumbent was supported by receipt of the lesser tithes and glebe land. ${ }^{58}$ Parishioners paid tithes and church rates and, in return for a right to a seat ${ }^{59}$ in the parish church, were placed under a legal obligation to keep the nave of the church in a state of repair. ${ }^{60}$

\section{The National Church Challenged: Lessons from the Nineteenth Century}

It would be wrong to suggest that there was any wholesale abandonment of the national ideal and the national mission of the Church of England in the nineteenth century. However, it is undeniable that the nation which the Church aspired to serve, and the constitutional framework within which it aspired to do so, changed radically in the mid to late nineteenth century. This was to have a profound impact upon the Church.

England in the late nineteenth century, though far from being the pluralist and increasingly secular State of the twenty-first century, was no longer, either in theory or reality, a Confessional State. Non-Anglicans had been accepted into the full life of the nation as citizens. Further, increasing

55 Aston Cantlow v Wallbank [2003] UKHL 37, at 130 - though these rights are subject to certain exceptions.

56 Limitations on space preclude a full discussion of this complex arrangement in its history. See Law Com. No. 152 (1985) Property Law: Liability for Chancel Repairs and J. H. Baker, 'Lay Rectors and Chancel Repairs', (1984) 100 LQR 181-185.

57 W. Dale, The Law of the Parish Church (7 th $^{\text {ed.) }}$ (London: Butterworths, 1998) p.27.

58 ibid. The cure of souls could also be held by a curate who had no property rights in the church and no right to receipt of tithes.

59 For a discussion of the history of this right see J. C. Fowler, Church Pews, their Origin and Legal Incidents, with some Observations of the Propriety of Abolishing them, in Three Chapters (London: Francis and John Rivington, 1844).

60 See Gosling v Veley (1853) 4 H.L. App. Cas. 679. Though generally the rector was liable for the repair of the chancel (per Hawkins v Rous (1695) Holt K.B. 139 cited in W. Dale, The Law of the Parish Church, p.72. 
numbers of Englishmen, though they did not actively dissent, were distanced from the Church by their own apathy and doubts. ${ }^{61}$

The Church experienced the anxieties and difficulties of a church which, though it had begun life as an embodiment of a confessional State, was increasingly alienated from the nation that it aspired to serve. It awoke to the reality that many citizens either rejected its services or, in a hurried and worried existence, did not feel that its services were of immediate use or importance to them. This reality prompted one eminent Churchman to cry:

"What is the national Church? - Who are her members? Does she number among her members the majority of the people? Let the truth be known. The computation of the numbers said to be within her pale is founded on a fallacy. The number of Papists and other Dissenters having been correctly ascertained, their aggregate is subtracted from the whole population, and the residue are always claimed by the Church of England and Ireland to be her members. It is not possible to conceive a mode of computation more deceptive."62

The social and political changes of the later nineteenth century, in addition to contributing to a sense of crisis in the Church, also had serious practical consequences for the mechanisms and arrangements by which it had historically supported its national mission. The increasingly non-Anglican character of Parliament led to pressure for mechanisms of Church government and administration independent of it. This culminated in the revival of convocations, diocesan synods, parochial church councils and, ultimately, the formation of the Church Assembly. ${ }^{63}$

Similar innovation was required in respect of Church maintenance and support. Tithes were devalued by falling agricultural prices and commuted by statute, rendering them of little value. Compulsory church rates were abolished by statute in 1868, and there was a swell of public opinion against the pew rents charged in many parishes, as contributing to the Church's failure to reach the poor. ${ }^{64}$ Further, as the Church sought to respond to the changing social demographics brought about by the Industrial Revolution, ways had to be found of supporting parishes and missions which were not supported by historic endowments. The net result was a greatly increased reliance upon voluntary action and private donations as a means of Church support.

61 See generally O. Chadwick, The Victorian Church, Vol.II (London: A. and C. Black, 1970) and O. Chadwick, The Secularisation of the European Mind in the nineteenth Century (Cambridge University Press, 1975).

62 R. Oastler, The Church and the People (London: C. W. Reynell, 1860) p.13.

63 See e.g. 'A Few Thoughts on the Laity by a Layman,' Contemporary Review, vol.13 (1870) p.86 and 'A Speech by J. T. Tomlinson Esq. at the Sheffield Church Congress, 1878,' in J. T. Tomlinson, Collected Tracts on Ritual (vol.I)(London: Church Association, 1899) p.4.

64 Though the Church was required by law to reserve free seats to the poor it was felt that the stigma attached to these seats, their poor position in the church, and the perpetuation of privilege all contributed to the alienation of the poor from the Church. See generally O. Chadwick, The Victorian Church (Vol.II). 
While the means of funding the Church changed so too did the parochial system which they had traditionally supported. One of the Church's first responses to the perceived needs of the rapidly swelling urban population was a Herculean effort to build new churches in the towns and cities. A side effect of this was an increasing mobility among urban congregations. The late nineteenth century was a time of sharp theological divisions within the broad confines of the Church. This, combined with a range of easily accessible churches in any geographical area, served to undermine and dissolve the traditional tie between a parishioner and his parish church. Urban parishioners increasingly chose to attend, not the parish church in respect of which their place of residence gave them rights, but rather the church which best reflected their ecclesiastical tastes and sensibilities. ${ }^{65}$

Another, and related, manifestation, of the changes to the traditional territorial system, was innovation in the mission of the Church to the masses. The urgent need to bring people to salvation, in concert with a profound appreciation of the growing numbers of people living outside of the daily influence of the Church, created this impetus to innovate. Church building schemes alone had not managed to Christianise the masses so other less orthodox strategies were applied. Mission meetings were held at Exeter Hall, services were conducted in parks and theatres, mission churches were established, all in an effort to reach the masses, and all existing outside of the territorial system. As a consequence of this increase in itinerant mission there existed a body of the laity who, though they might have called themselves Churchmen and women, took no part in the parochial, territorial system. ${ }^{66}$

The changes just described distorted and weakened the parochial and territorial system by which the Church had traditionally aspired to fulfil its national mission. More broadly, however, social and political changes raised a profound challenge to the involuntary model of Church membership which underpinned that aspiration. Though the law continued to assert that model of membership, ${ }^{67}$ a sense of alienation from the wider nation, together with initiatives for the formation of representative church councils, and reliance on lay action for Church support and maintenance, contributed to the practice of differentiating between the laity and other citizens. For an increasing number of purposes the Church adopted the voluntary model of membership which typified independent religious bodies and required individuals to take positive steps to assert their membership of the Church. As such, individuals began to experience a differentiation between their duties as lay members of the Church and as citizens of the State. ${ }^{68}$

65 For a panoramic picture of the Church at this time see generally O. Chadwick, The Victorian Church (Vol.II).

66 ibid.

67 See, e.g. Escott v Mastin 4 Moo PCC 104 and Combe v Edward (1876) 4 A \& E 390.

68 See generally M. J. D. Roberts, The Role of the Laity in the Church of England c1850- 1885 . 
Finally, while many Churchmen strongly defended the national identity and broadly national mission of the Church, ${ }^{69}$ the theological concerns of others placed further pressures on the traditional involuntary model of Church membership. At one extreme of the range of thinking on Church membership were many, but by no means all, members of the Oxford Movement, and those with Ritualist sympathies. For these Churchmen the doctrinal unity and purity of the Church, the spiritual identity of which they emphasised, and for which they sought a source of authority untrammelled by the State, was significantly more important than concerns to maintain a broad and nationally based membership. Their preoccupations with the doctrinal unity of the Church as a pure spiritual body often caused them to take a selective approach to Church membership. ${ }^{70}$

At the other end of the spectrum stood the Evangelicals, whose focus was not the purity or authority of the Church but rather the faith and Salvation of individuals. A central feature of Evangelicalism was the drive to save individual souls. This in itself mitigated against any tendency which might narrow the Church and impair its capacity to reach and serve the masses. In addition Evangelicalism was, as a movement, influenced by forms of theological thought which tempered any disposition to narrow definitions of the Church. Some Evangelicals, for example, were influenced by Calvinistic thought. As such they maintained a clear distinction between the Church on earth - which contained both the elect who would achieve eternal life and the non-elect who had not been saved - and the One Church - which contained only the elect who had been saved. Such Calvinistic doctrine tended in itself to undermine the notion, so essential to the Oxford Movement, of the Church as a body of the faithful. Other Evangelicals, were much influenced by Arminianism, which emphasised the belief that Christ died to save all who believed. This, rather than undermining the vision of the Church as a body of the faithful, made that body as wide and inclusive as possible, ${ }^{71}$ thus once again contrasting with the more elitist approach of the Oxford Movement and its successors. $^{72}$

\section{The Conundrum Created by Establishment and Political and Social Change}

The conundrum created by Establishment stemmed from the junction at its heart between Church and State, and the inextricable links that it created

69 See, e.g. H. B. Wilson, 'Seances Historiques de Geneve', T Hughes, This Old Church, What Shall we do with it? (London: Macmillan, 1878) and a variety of speeches at the Church Congress of 1883.

70 See, e.g. Parl. Deb. ( $3^{\text {rd }}$ Ser.) CCXIX, col. $1138-39$ and Address Delivered at the Special Meeting of the English Church Union on Tuesday January 161877 (London: E.C.U., 1877).

71 Both Calvinism and Arminianism cut across party lines within the Church and were by no means unique to Evangelicalism.

72 Once again constraints on space prohibit a full and detailed account of the Evangelical position and theology however see generally D. W. Bebbington, Evangelicalism in Modern Britain: A History from the 1730s to the 1980s (London: Unwin Hymen, 1989), I. Bradley, The Call to Seriousness: The Evangelical Impact on the Victorians (London: Cape, 1976), and B. Hilton, The Age of Atonement: The Influence of Evangelicalism on Social and Economic Thought, 1795-1865 (Oxford: Clarendon Press, 1988). 
between Church and State, and Church and nation. This junction created a fundamental ambiguity in the determination of the character and identity of the Church of England. This ambiguity was compounded by the very different reactions of different sections of the Church to the situation in which it found itself.

\section{The Ambiguity Created by the Relationship between Church and State}

The Church, as revealed by the survey of the legal aspect of Establishment, was closely tied to the State, and, by virtue of Establishment, had recourse to the civil power in essential matters of its life and discipline. Ecclesiastical laws could, for example, be enforced in the last resort by the coercive powers of the State. Similarly, the final appeal in ecclesiastical causes was to the Crown, while a significant body of ecclesiastical law was enacted by Parliament. In essence Establishment conferred upon the Church two modes or sources of action in respect of its regulation and discipline, and two sources of identity. In many matters it acted through things, such as the pastoral jurisdiction of the bishop, which accrued to it by virtue of its status as a church without reference to the State. In other matters it expressly appealed to things, such as parliamentary legislation and coercive jurisdiction, which were only open to it as a result of its links to the State.

While both Church and State, though in many ways different, shared a spiritual identity, and an essential unity or union as different aspects of the nation, there was little difficulty in the availability of these two distinct courses of action. Though the authority and jurisdiction of Church and State were possessed of different concerns and modes of action, both were, in essence, spiritual. Whether the Church chose to proceed via those powers it had apart from its relationship with the State, or by powers at its disposal by virtue of that relationship, it appealed fundamentally to authority or modes of action which were essentially spiritual or divinely ordained. It was unambiguously a spiritual body.

The ambiguity or conundrum arose when, in the face of constitutional change, some (but not all) parts of the Church lost sight of the shared spiritual identity and unity of Church and State as different aspects of the nation. Church and State remained united in law but this was no longer seen as a union of two types of spiritual institution. It was seen instead as a union of the secular and the spiritual. Moreover, when the Church had recourse to the civil power, for example in legislation or the final appeal to the Crown, this was seen as an appeal to secular power. Thus it appeared that, by virtue of Establishment, there was a junction of the secular and the spiritual, and that the Church had a proper appeal to secular and spiritual authority. Further, it also appeared that the Church, though a spiritual body, was in some respects also a religious (or even secular) institution defined by its relationship with the State. 


\section{The Ambiguity Created by the Relationship between Church and Nation}

Establishment created a dual identity or personality for the Church, as both a religious institution tied to the State, and as a spiritual body which appealed to God for its authority, wholly independent of the State. ${ }^{73}$ This duality was mirrored in definitions of the membership of the Church. It could define itself by relation to its geographical relationship with the nation and its role as a national church. Thus Halsbury's Laws of England, for example, defined the Church as:

"[T]he branch of the Church which was founded in England when the English were gradually converted to Christianity between the years 597 and 768." 74

It could also define itself, not by reference to its territorial limits or national role, but by reference to a core measure of doctrinal unity, or unity in belief, shared by its members. Thus Article XIX of the Articles of Religion defined the Church as:

"A congregation of faithful men, in which the pure word of God is preached, and the Sacraments be duly administered according to Christ's ordinance in all those things that of necessity are requisite to the same."

While the Confessional State existed, at least in theory, the two types of definition could identify the same persons as members of the Church. This was not the case in the later nineteenth century. As such two models of membership, and two identities, came into conflict. The definition focussed on territorial extent supported an involuntary model of membership, which contributed to the identity of the Church as a national institution. By contrast, a definition focussed on doctrinal unity supported a voluntary model of membership which contributed to the identity of the Church as a private spiritual body or membership society.

\section{Establishment Today: Stasis, Change and a Very Real Conundrum}

What follows is a brief description of the constitutional arrangements which today form the Establishment, and a demonstration of the continuing relevance of the problems experienced in the nineteenth century.

\section{Establishment as a Relationship between the Church and the Organs of the State}

The doctrine of Royal Supremacy remains at the heart of the modern Church's doctrine of the relationship between Church and State. Canon A7 asserts that the Sovereign:

73 See, for example, S. T. Coleridge, On the Constitution of Church and State, chapter five, and R. Palmer, The Endowment and Establishment of the Church of England, p.4.

74 Halsbury's Laws of England ( $4^{\text {th }}$ ed.) (2000) vol.14, para.345. 
". . . acting according to the laws of the realm, is the highest power under God in this kingdom, and has supreme authority over all persons in all causes, as well ecclesiastical as civil."

The Royal Supremacy, and the more modern doctrine of Parliamentary Sovereignty, are expressed in all areas of Church administration, government, legislation and adjudication. While there has been an undeniable tendency to distance those matters from State control, and to increase the Church's abilities of self-determination, there has been no break of the intimate connection between Church and State.

Looking first at the mechanism for appointing Anglican bishops, the essential elements of this system remain unchanged, and the Crown continues to appoint the Church's bishops. In some respects, however, the practical reality of this system has altered in recent years. Following the inception of the present constitutional arrangements in the Bill of Rights 1688, entailing a constitutional or limited Monarchy, it is the Prime Minister, rather than the Monarch, who appoints bishops. Further, following demands for greater Church influence in the appointment of its bishops, the Prime Minister has, since 1977, been aided by the Crown Appointments Commission. This Church body presents the Prime Minister with two candidates for appointment. The Prime Minister is under no obligation to accept these candidates but, by convention, will normally appoint the first named candidate. ${ }^{75}$ He no longer has a completely free rein in Church appointments. ${ }^{76}$

A similar combination of stasis and change can be seen in relation to Church government and the Church's powers to make canon law, and to legislate by other means. As such, while the organs of the Church no longer require the licence of the Queen to meet and make canon law, it remains the case, under the Synodical Government Measure 1969 section 1(3)(b), that the General Synod cannot generally pass canons which are repugnant to the royal prerogative or other laws and customs of the realm. This limitation no longer applies to matters of worship or the assent to doctrine. ${ }^{77}$ Ultimately, however, the Church must still obtain the assent of the Queen before its canons can be promulgated. ${ }^{78}$

In respect of Church government, the Church of England Assembly (Powers) Act $1918^{79}$ created the Church Assembly, a national deliberative and administrative body for the Church outside of Parliament. This trend was continued by the Synodical Government Measure 1969, which established the 'new and improved' General Synod.

75 See Julian Rivers, 'From Toleration to Pluralism: Religious Liberty and Religious Establishment under the United Kingdom's Human Rights Act,' in R. J. Ahdar (Ed.), Law and Religion (Aldershot: Ashgate, 2000).

76 It appears though that, however exceptionally, the current Prime Minister has twice breached convention and rejected the Church's first named candidate. See K. Medhurst, 'The Church of England: A Progress Report', (1999) Parliamentary Affairs pp.275-290.

77 See the Church of England (Worship and Doctrine) Measure 1974 s.6(1).

78 See the Synodical Government Measure 1969 s.1(3)(a).

799 \& 10 Geo. 5 c. 76 . 
These innovations in the sphere of Church government, and a general dissatisfaction with being reliant upon the interventions of an increasingly busy and pluralistic Parliament, also led to reform in the area of ecclesiastical legislation. The Church of England Assembly (Powers) Act 1918 gave the Church Assembly - and later the General Synod - the power, subject to the final approval of Parliament and the Royal Assent, to pass legislation on matters concerning the Church of England. Under the framework provided by that Act the Legislative Committee of the General Synod lays legislation before the Ecclesiastical Committee of Parliament, which then reports to Parliament on whether the proposed legislation is expedient or not. Parliament can decline to pass the legislation laid before it but it cannot amend the legislation. If the legislation is passed then it becomes a Measure and is a form of primary legislation. Yet, even if the Church has in this way gained a considerable degree of autonomy, it is still ultimately subject to the authority of the Queen in Parliament. ${ }^{80}$

Turning next to the courts one sees perhaps the greatest changes to the traditional embodiments of Establishment. Remnants of the coercive jurisdiction of ecclesiastical courts remain. Under the Ecclesiastical Jurisdiction Measure 1963 s81, for example, an Episcopal Court retains powers to compel the attendance of witnesses and to condemn individuals in costs. However that jurisdiction has very largely passed into history. Similarly, the appellate jurisdiction of the Crown has all but disappeared. Although, under the Ecclesiastical Jurisdiction Measure 1963 section 1(3)(d), the Judicial Committee of the Privy Council remains the court of final ecclesiastical appeal in respect of faculty cases which do not raise matters of doctrine, ritual or ceremonial; jurisdiction (both original and appellate) in matters of worship, doctrine and ritual now rests with the Court of Ecclesiastical Causes Reserved. Though that court is staffed by judges appointed by the Queen, an appeal to it does not constitute an appeal to the Crown. ${ }^{81}$

One area of constancy is the status and character of ecclesiastical law. This maintains its heterogeneous character and remains part of the ordinary law of the land. It is not, in the contemplation of the law, the law of a private membership body.

\section{Establishment as a Relationship between Church and Nation}

The expression of Establishment as a relationship between Church and nation remains much the same as it did on the late nineteenth century. The Church continues to proclaim a national mission, ${ }^{82}$ and it still seeks to fulfil that mission primarily through the parochial and territorial systems supported by its historic endowments. However, as in the nineteenth century, there is a

80 Some scholars have pointed to the reluctance of Parliament to use its veto of Church Measures as an indication that the State will not intervene in Church matters. However others have demonstrated that Parliament, though reluctant to veto, plays an active role in shaping Church legislation. See V. Bogdanor, The Monarchy and the Constitution (O.U.P., 1995) ch.9 and J. Behrens, 'The Churchwardens Measure', (2001) 6 Ecc. LJ 97-110.

81 See the Ecclesiastical Jurisdiction Measure 1963 s.1(3)(b).

82 See the Church of England's submission to the Wakeham Commission (Cm 4534, 2000). 
recognition that many individuals are alienated from the Church, and that this poses challenges for the Church and its organisation. So, for example, one inner city bishop has recently proclaimed:

"We live on the cusp of modernity and post-modernity. The one will not erradicate the other but our task as a national church is to minister to people for whom there are no metanarratives or paradigms, where the old certainties have disappeared, and for whom the virtue of diversity and choice has become absolute... The task of the Church in worship and mission is to engage with people who are rapidly losing the grammar of the Christian faith (or indeed have never learned it), many of whom are none the less deeply religious." ${ }^{83}$

The same bishop, though he clearly stated his commitment to the national mission of the Church and the parochial system by which it was traditionally supported, echoed the frustrations of many of his nineteenth century forebears, stating:

"It is time for the Church of England to reinvent itself and create new paradigms of church while not forsaking the traditional structures. But we cannot do that while the ecclesiastical legal framework is more concerned with the rights of freeholders, patrons and parishioners who never set foot inside their parish church than with the solemn and primary task of making possible the encounter of human beings with the God who created them for a relationship with himself." $" 84$

This statement illustrates the modern relevance of the tensions, demonstrated above in relation to the nineteenth century, between the historical position, aspirations and structures of the Church of England, and the current state and needs of the nation which it still aspires to serve.

That tension is further illustrated in current legal approaches to the membership of the Church of England, lay rights and representative Church bodies. The rights of individuals in respect of the services of the Church continue to be defined, prima facie, in relation to a geographical relationship with a parish church. Similarly, the law assumes that an individual parishioner who claims rights in respect of a church is a member of the Church of England. ${ }^{85}$ However, recent Measures have recognised the creation of individual rights where, though an individual does not live in a parish, they habitually worship at the church of that parish. ${ }^{86}$ So, too, while the law assumes that an individual is a member of the Church for the purpose of the vindication of basic rights, for other purposes it imposes more stringent requirements upon individuals. Thus, for example, those seeking to

83 The Rt. Revd. Pete Broadbent, Bishop of Willesden, 'Desperate Measures', (2002) 6 Ecc. LJ 390.

84 ibid., p.394.

85 See, e.g. Marshall v Graham [1907] 2 KBD 112 at 124 and Faith v Allen [1953] Ch.116.

86 See, e.g. church Representation Rules, r.1(2)(a) and r.1(2)(b). 


\section{Northern Ireland Legal Quarterly [Vol. 56, No. 3]}

be appointed as churchwardens must be baptised, to have their names upon the electoral roll of the parish, and to be actual communicants. ${ }^{87}$

\section{The Modern Relevance of the Conundrum Created by Establishment}

The continued relevance of the conundrum created by the combination of Establishment and constitutional and social change in the nineteenth century is self-evident today. Though the State retains many of the trappings of its Christian and confessional past, it is now an avowedly pluralist State. Indeed, there is a commonly expressed belief that it is increasingly secular. ${ }^{88}$ Few today would have sympathy with the claims of the State to be a spiritual body. They might instead be more inclined to favour the sentiment expressed in MacIntyre's assertion that the State is:

"[A] dangerous and unmanageable institution, presenting itself on the one hand as a bureaucratic supplier of goods and services, which is always about to, and never does, give its clients value for money, and on the other as a repository of sacred values, which from time to time invites one to lay down one's life on its behalf. As I have remarked elsewhere . . . it is like being asked to die for the telephone company." $"$

While the State has lost its spiritual identity, the nation has manifestly become more multicultural and multi-faith than ever before. While the majority of citizens still maintain some links or sense of affiliation with Christianity, the majority of citizens are no longer Anglicans, and a significant minority of them belong to other faith communities. ${ }^{90}$

Establishment remains largely intact. By virtue of it the Church is tied to an increasingly secular State and an increasingly heterogeneous nation. How then is it to define itself? The answer is in a multitude of different ways depending on the context in which it is being required to make that definition, and depending upon the people asked in what is self-consciously a very broad church. The result is an ambiguity which has consequences for the legal and constitutional treatment of the Church of England today.

87 Churchwardens Measure 2001 s.1(3). Under the Church Representation Rules R54 defines an actual communicant as a person who has received communion according to the rites of the Church at least three times in the preceding 12 months.

88 See, e.g. D. Harte, 'Defining the Legal Boundaries of Orthodoxy for Public and Private Religion in England', in R. O'Dair and A. Lewis (Eds.), Law and Religion (Oxford, 2001).

89 A. MacIntyre, 'A Partial Response to My Critics,' in J. Horton and S. Mendus (Eds.), After MacIntyre: Critical Perspectives on the Work of Alistair MacIntyre (Notre Dame: University of Notre Dame Press, 1994) p.303.

90 See the 2001 Census. 


\section{A Demonstration of the Conundrum: Aston Cantlow v Wallbank and the Treatment of Anglican Institutions and their Functions Under the Human Rights Act section 6}

In Aston Cantlow v Wallbank the House of Lords, and the Court of Appeal before it, came face to face with the conundrum posed by Establishment in the modern constitution. They were asked to consider the status of Anglican Parochial Church Councils, and the nature of their function in enforcing chancel repair obligations, for the purposes of section 6 of the Human Rights Acts 1998. The courts were asked to determine whether PCCs were public authorities, or whether, if not public authorities per se, when enforcing an obligation to repair the chancel of a parish church they were performing a function of a public nature. To answer these questions the courts were required to confront the ambiguity surrounding the identity, functions and membership of the Church of England and its institutions. ${ }^{91}$

\section{The Majority Decision in the House of Lords}

The treatment accorded to the Church of England, chancel repair obligations, and PCCs by the House of Lords was profoundly influenced by European Human Rights Jurisprudence. Following that jurisprudence, and relying upon Article 34 of the ECHR, their Lordships asked the question whether the body concerned was a governmental body, and not, as in the domestic jurisprudence which dominated in the reasoning of the Court of Appeal, whether it was a public body.

The use of the word 'governmental' led to a collision with the difficulties and controversies of the late nineteenth and early twentieth centuries. In finding that neither the Church in general, nor PCCs in particular, were governmental bodies their Lordships relied on the famous dictum of Phillimore J that:

"A Church which is established is not thereby made a department of the State. The process of establishment means that the State has accepted the Church as the religious body in its opinion truly teaching the Christian faith, and given to it a certain legal position, and to its decrees, if rendered under certain legal conditions, certain civil sanctions." ${ }^{.92}$

Their reliance upon this dictum quite reasonably took no account of its history. That history is that it was made by a militant High Churchman, who advocated disestablishment, and protested against all forms of secular interference in the affairs of the Church as an unwarranted intrusion upon its

91 For a thorough examination of this see A. Pearce, 'Aston Cantlow: Chancel repairs and the Status of Church of England Institutions', Law and Justice 151 (2003). For general critical comment on the decision and HRA 1998 s.6 see F. Meisel, 'The Aston Cantlow Case: Blots on English Jurisprudence and the Public/Private Law Divide', [2004] P.L. 2-10; L. Turano, 'Restoring Chancels and Human Rights', [2004] CLJ 7-9; P. Cane, 'Church, State and Human Rights: Are Parish Councils Public Authorities', (2004) 120 LQR 41-48; and D. Oliver, 'Functions of a Public Nature Under the Human Rights Act' [2004] PL 329-51.

92 Marshall v Graham [1907] 2 KBD 112 at 126. 
spiritual authority. ${ }^{93}$ It was made at a time when some politicians and Churchmen still advocated extensive State control of the Church, and the supremacy of secular authority over spiritual concerns. ${ }^{94}$ It is arguable that, though many of these concerns have been mitigated by the reforms of the twentieth century, an unwary reliance upon the dictum led to the House of Lords being unduly reticent in its treatment of Establishment.

A further cause of such reticence might be found more generally in the Human Rights framework within which the court had to determine the case. As many scholars have noted, that framework tends to relegate religion to the private sphere, and to treat it as something with which the State cannot interfere. It does so by setting the individual and the State in opposition to each other, and by framing rights in terms of State duties of noninterference. ${ }^{95}$

The influence of this jurisprudence is clear in the reasoning of the majority of their Lordships. In reasoning from Article 34 they held that neither the Church nor the PCC could be a core public authority because that would mean that, in distinction to other religious bodies, they could not vindicate their Convention rights. ${ }^{96}$ Equally, applying the "governmental test" caused them to assert that the character and functions of the bodies concerned were essentially private, as they were unable to find that the maintenance and provision of religious services was something for which the State would otherwise provide. In sum, it caused the majority, in deferring to the spiritual identity of the Church, to pay scant regard to its public status as a religious institution which is closely tied to the State and exercises a national role and mission.

This tendency to draw a sharp contrast between the secular State and the spiritual and essentially private character and functions of the Church, is reflected in their Lordships' definitions of Establishment. So, for example, Lord Nicholls maintained a careful distance between Church and State, and a clear distinction between what was governmental and what was spiritual and private, holding:

"Historically the Church of England has discharged an important and influential role in the life of this country. As the established Church it still has special links with central government. But the Church of England remains essentially a religious organisation. This is so even though some of the emanations of the Church discharge functions which may

93 See his book W. G. F. Phillimore, The Government of the Church in Relation to the State and the Laity (187? at LPL, reprinted from the Union Review).

94 See, e.g. the speeches and letters of Sir William Harcourt - a typical example is found in The Times $20^{\text {th }}$ July 1874 .

95 See J. Rivers, 'From Toleration to Pluralism: Religious Liberty and Religious Establishment under the United Kingdom's Human Rights Act', pp.138-62 in R. J. Adhar (Ed.), Law and Religion (Aldershot: Ashgate, 2000); S. C. Van Bijsterveld, 'Religion, International Law and Policy in the Wider European Arena: New Dimensions and Developments', pp.163-80 in R. J. Adhar (Ed.), Law and Religion and S. C. Van Bijsterveld, 'Freedom of Religion: Legal Perspectives', pp.299-310 in R. O'Dair and A. Lewis (eds.), Law and Religion.

96 See [2003] UKHL 37 at para.8. 
qualify as governmental ... This should not be regarded as infecting the Church of England as a whole, or its emanations in general, with the character of a governmental organisation." 97

Lord Hope, too, carefully preserved the spiritual identity of the Church, holding:

"What establishment in law means is that the state has incorporated its law into the law of the realm as a branch of its general law ... The Church of England is identified with the state in other ways, the monarch being the head of each . . It has regulatory functions within its own sphere, but it cannot be said to be part of government. The state has not surrendered or delegated any of its functions or powers to the Church. None of the functions that the Church of England performs would have to be performed in its place by the state if the Church were to abdicate its responsibility ... The relationship which the state has with the Church of England is one of recognition, not of the devolution to it of any of the powers or functions of government." 98

Their Lordships maintained this emphasis upon the Church's identity as a spiritual body in their treatment of PCCs. As such they focussed on their formulation under Measure and their primary role as being to aid the minister in furthering the mission of the Church in the parish - holding this to be an innately private and spiritual function. In some respects this was well founded, for, as noted, these bodies were the product of a need to provide a forum for Church administration in which only active conformists were able to participate. ${ }^{99}$

Yet their Lordships neglected the intertwining of that "private membership" aspect of PCCs with the historic ideals and framework of a national church. As such they failed to note that the duty to enforce chancel repair obligations came to PCCs from the parish vestries, which exercised civil and spiritual functions and were the very embodiment of the close territorial and administrative relationship between Church, State and nation. ${ }^{100}$ This, in turn, caused them to focus upon a characterisation of the Church and PCCs as serving a membership body, rather than the nation as a whole. ${ }^{101}$

The majority carried this view into their characterisation of the obligation at the heart of the case. The obligation to repair the chancel attached to ownership of rectoral land and was part of the historic system of public taxation by which the State provided for the services of religion in parish churches. It was an obligation undertaken in consequence of the rector's right to receive tithes. This right was effectively abolished and, following

97 ibid., para.13.

98 ibid., para.61.

99 ibid., para.14, 59, 86 and 156

100 This point is noted in the Court of Appeal. See [2001] EWCA Civ 713 at paras. 32-35. See also, A. Pearce, Submission to the Joint Committee on Human Rights - published as an appendix to the $7^{\text {th }}$ report of the 2003-4 session (HL39, HC 382).

101 Op.Cit. n.98. 
the Chancel Repairs Act 1932, the obligation to repair chancels took the form of private law obligation. Having summarised this history the majority held that the enforcement of the chancel repair obligation was analogous to the enforcement of any other private law obligation or civil law debt. In doing so they dismissed its place in the system of State support which supported the ideal and mission of a national and Established Church. ${ }^{102}$

In short, the treatment accorded to Establishment by the majority in the House of Lords demonstrated a determination to treat the Church of England as it would any other religious body. ${ }^{103}$ Within the Human Rights context this grew out of a focus on its identity as a spiritual body which exists independent of the State and can determine its own actions.

\section{The Dissenting Judgment of Lord Scott}

In fact there was one lone voice speaking in the House of the Lords for the traditional identity and role of the Church of England as a religious institution closely linked to the State and ministering to the nation. Lord Scott strongly asserted that traditional role of the Church, the general applicability of rights in respect of its worship and rites as a matter of law, and the history of State interest and support which underpinned them.

Though Lord Scott rejected the argument that PCCs were "core" public authorities for the purposes of HRA s6, he accepted the argument that, in enforcing the obligation to repair the chancel, they were executing a function of a public nature under s6(3)(b). In doing so he asserted strongly the public and national status and mission of the Church under Establishment, holding:

"The important factors and matters relevant to the question in the present case seem to me, in no particular order of importance, to be the following. (1) The parish church is a church of the Church of England, a church by law established. (2) It is a church to which the Anglican public are entitled to have recourse, regardless of whether they are practising members of the church, for marriage, for baptism of their children, for weddings, for funerals and burial, and perhaps for other purposes as well. (3) Members of other denominations, or even of other religions, are, if parishioners, entitled to burial in the parish churchyard. (4) The church is, therefore, a public building. It is not a private building from which the public can lawfully be excluded at the whim of the owner. (5) ... (6) A decision by a PCC to enforce a chancel repairing liability is a decision taken in the interests of the parishioners as a whole. It is not taken in pursuit of any private interests. If it were so taken, it would I think be impeachable by judicial review."104

This characterisation of the Church caused him to reject the notion that the enforcement of the chancel repair obligation was a private matter, because

102 [2003] UKHL 37 at paras.16, 64, and 89.

103 Indeed the majority took as authority for the private status of religious bodies the Wauchmann Case ([1993] 2 All ER 249) which concerned a Jewish body which enjoyed no formal constitutional relationship with the State.

104 [2003] UKHL 37 at para.130. 
enforcement was undertaken on behalf of all 'parishioners' and not on behalf of a congregation or private membership body.

\section{The Court of Appeal}

Like Lord Scott the Court of appeal had emphasised the public and national character and status of the Church of England and its institutions and their functions. At every stage of the judgment of the court Sir Andrew Morritt highlighted the dual character of the Church and its institutions in consequence of Establishment. Thus, for example, he held:

"The Church of England has enjoyed a unique status ... since the passage in 1532-4 of the five statutes which severed the hegemony of Rome and placed the Church under the spiritual and temporal sovereignty of the Crown; this not withstanding its theological continuity since Saxon times . . . Both the spiritual and the temporal courts were thenceforth the King's courts, and it is by the latter that the liability of first spiritual and then lay rectors to repair the chancel has been both enunciated and enforced." 105

Similarly, he recognised that PCCs had both civil and spiritual functions, asserting:

"The PCC itself exemplifies the special status of the Church of which it forms part ... The successor of the vestry, the PCC is constituted not as a voluntary association but by law. In the exercise of statutory powers originating .... in the Act of Supremacy 1568, but found more immediately in the Church of England Assembly (Powers) Act 1919, the Parochial Church Councils (Powers) Measure 1956 as amended provides for the discharge of the functions of the PCC and, by s3, constitutes it a body corporate. That a measure of its National Assembly can make every PCC a statutory corporation is an index both of the public character of the Church of England and (to some extent) of the PCC. The functions of the latter, which include but are not confined to those set out in s2 of the Measure, subsume those of the vestry (s4) which included both spiritual and civil matters." 106

This approach and emphasis differed greatly from that of the House of Lords. One possible explanation for this is that the Court of Appeal focussed largely on domestic jurisprudence on the public-private divide. ${ }^{107}$ As such they were not confronted with the application of words such as "governmental" in respect of the Church or its institutions. Further, it is arguable that they were set at a greater remove from the discourse which today tends to allocate religion to the private sphere.

105 [2001] EWCA Civ 713 at para.31.

106 ibid., para. 32.

107 See e.g. ibid., paras. 34 and 35. 


\section{Conclusion}

This article has sought to examine the social, political, theological and constitutional and historical forces which continue today to contribute to a profound difficulty in legal and constitutional attempts to address the position and treatment of the Church of England.

It has been contended that Establishment, by creating a junction between Church, State and nation, has created a source of ambiguity in allocating to the Church diverse identities and appearances. The conundrum which it presents is exacerbated both by the apparently secular or plural identity of the State and nation to which the Church is joined, and the diversity of reactions to that junction. As the reasoning of the House of Lords in Aston Cantlow v Wallbank demonstrates, old difficulties are rendered more acute as a result of the Human Rights context within which the courts now operate. This brings into play distinctions and attitudes which are not contemplated within the historic character and aims of Establishment. The result is a fundamental inconsistency in our current constitutional arrangements. The House of Lords showed an unwillingness to recognise and accord significance to the national and public role of the Church. Yet in our arrangements for the coronation of our Monarchs, the composition of the second chamber, our blasphemy laws, Episcopal appointments, and national religious events we continue - for the present at least - to recognise that very public and national character. 